\title{
Margaret McCartney: Pointless paperwork, not patients, is what GPs should avoid
}

\author{
Margaret McCartney general practitioner
}

Glasgow

Winter's coming, there's flu in the southern hemisphere, and the canaries have stopped singing in general practice. I have a visceral sense of dread.

Jeremy Hunt recently spoke to GPs about "the $26 \%$ of GP appointments that GPs themselves say are potentially avoidable."1 He talked about 10 "high impact actions" aimed at releasing capacity, which form part of the Releasing Time for Care programme, put together at a cost of $£ 30 \mathrm{~m}$.

Essentially, says NHS England, "most common potentially avoidable consultations were amenable to action by the practice, often with the support of the clinical commissioning group." Some $7 \%$ of patients could be diverted elsewhere in the practice, $6 \%$ could be seen at a pharmacy or asked to self care, and 3\% could be seen by a "care navigator," it explains.

Hunt's statistics were based on a survey of "over 50" GPs who gave their own opinion on "almost 5000" consultations. ${ }^{3}$ The terminology nags at me: contacts with patients were divided into "avoidable" and "unavoidable." I'd prefer to think of appointments in terms of whether the patient considers me the best person to help, and whether I agree.

And I'd like to know whether the "problem" being presented should have been a problem at all. I'm thinking, for example, of the mess of medical examinations for welfare benefits, where consequent damage to patients' mental health is inflicted by private providers and left for patients and primary care to absorb. Or patients who phone the hospital for results of a test organised by secondary care but are told to contact their GP if they don't want to wait until their outpatient appointment.

The programme of work being embarked on in England is predicated on the belief that some patients don't need to see the doctor. This may be true, but it's much easier to know in retrospect. General practice is magnificently complicated, defying clean pathways and templates.

The variety and scope of projects now being rolled out in the name of quality improvement is huge

The Department of Health clearly seeks to manage our profession remotely, particularly with online appointment booking. The variety and scope of projects now being rolled out in the name of quality improvement is huge. ${ }^{5}$ But searching and reporting of harms is scant, reporting of outcomes is highly variable, and negative projects don't seem to be reported. And where's the evidence that working differently will reduce workload or clinical contact time? ${ }^{6}$ The situation is too urgent and important to neglect high quality research.

Some proposals—such as for social prescribing —are recommended despite a lack of evidence. ${ }^{7}$ Other recommendations for "personal resilience" imply that resilience is in the control of the individual and is little related to environmental strain. Mindfulness training should be "embedded" in organisations, and doctors should have "an annual preventive health assessment" and "make home a sanctuary."

You may wish to scream. I merely insist, "Citation needed." For something is missing from this approach: evidence and a mirror. GPs are asked to do screeds of non-clinical contract work, which is time consuming, demoralising, and largely pointless. It's this that we should class as the "avoidable contact," and which should be razed.

Competing interests: See www.bmj.com/about-bmj/freelancecontributors/margaret-mccartney.

Provenance and peer review: Commissioned; not externally peer reviewed.

Follow Margaret on Twitter, @mgtmccartney

Jeremy Hunt's speech to the RCGP conference. Pulse 2017;359. www.pulsetoday.co.uk home/finance-and-practice-life-news/in-full-jeremy-hunts-speech-to-the-rcgp-conference/ 20035471.article.

2 NHS England. Reducing pressure in general practice. https://www.england.nhs.uk/gp/ gpfv/workload/releasing-pressure/.

3 Clay H, Stern R. Primary Care Foundation, NHS Alliance. Making time in general practice. Oct 2015. www.primarycarefoundation.co.uk/images/PrimaryCareFoundation/ Downloading_Reports/PCF_Press_Releases/Making-Time-in_General_Practice_FULL_ REPORT_28_10_15.pdf.

4 Primary Care Foundation. Assessing the numbers of potentially avoidable appointments. www.primarycarefoundation.co.uk/images/NHS_England-Audit_Tool_Paper_Version_ v06012015.pdf.

5 NHS England. Case studies. https://www.england.nhs.uk/gp/gpfv/workload/releasingpressure/case-studies/. 
6 Newbould J, Abel G, Ball S, et al. Evaluation of telephone first approach to demand management in English general practice: observational study. BMJ 2017;359:j4197. doi: 10.1136/bmj.j4197 pmid:28954741.

7 Bickerdike L, Booth A, Wilson PM, Farley K, Wright K. Social prescribing: less rhetoric and more reality. A systematic review of the evidence. BMJ Open 2017;359:e013384. doi:10.1136/bmjopen-2016-013384 pmid:28389486.
8 NHS England. High impact actions: topic sheet 6.2-personal resilience. https://www. england.nhs.uk/wp-content/uploads/2016/03/releas-capcty-6-topic-sht-6-2.pdf.

Published by the BMJ Publishing Group Limited. For permission to use (where not already granted under a licence) please go to http://group.bmj.com/group/rights-licensing/ permissions 